\title{
Two for the Price of One? The Contribution to Development of the New Female Elites
}

\author{
Alison Wolf*
}

July 2010

\begin{abstract}
This paper describes the very different role played by female elites in contemporary developing countries, as compared to the 'early' industrializing countries of the nineteenth and early twentieth century. It shows that women are far more important in business and politics in today's developing countries than they were in developed countries at a period when the latter had equivalent, and indeed significantly higher, levels of income per capita. It outlines the way in which this greater equality is rooted in educational opportunities; and argues that both educational provision, and women's entry into the elites, must be understood with reference to changing values and attitudes. They are not simply economically determined. Finally, the paper underlines the way in which these features of business and politics strengthen elite families in developing economies.
\end{abstract}

Keywords: elites, higher education, women, development, economic history, families

JEL classification: J16, J20, I23, O15

Copyright (C) UNU-WIDER 2010

* King’s College London, e-mail: alison.wolf@kcl.ac.uk

This study has been prepared within the UNU-WIDER project on The Role of Elites in Economic Development, directed by Alice Amsden, James Robinson, and Alisa DiCaprio.

UNU-WIDER gratefully acknowledges the financial contributions to the research programme by the governments of Denmark (Royal Ministry of Foreign Affairs), Finland (Ministry for Foreign Affairs), Sweden (Swedish International Development Cooperation Agency-Sida) and the United Kingdom (Department for International Development-DFID). 


\section{Acknowledgements}

Harriet Paterson provided valuable research assistance in the preparation of this paper, and her help is gratefully acknowledged.

Tables and figures appear at the end of the paper.

The World Institute for Development Economics Research (WIDER) was established by the United Nations University (UNU) as its first research and training centre and started work in Helsinki, Finland in 1985. The Institute undertakes applied research and policy analysis on structural changes affecting the developing and transitional economies, provides a forum for the advocacy of policies leading to robust, equitable and environmentally sustainable growth, and promotes capacity strengthening and training in the field of economic and social policy making. Work is carried out by staff researchers and visiting scholars in Helsinki and through networks of collaborating scholars and institutions around the world.

www.wider.unu.edu publications@wider.unu.edu

UNU World Institute for Development Economics Research (UNU-WIDER)

Katajanokanlaituri 6 B, 00160 Helsinki, Finland

Typescript prepared by Janis Vehmaan-Kreula at UNU-WIDER

The views expressed in this publication are those of the author(s). Publication does not imply endorsement by the Institute or the United Nations University, nor by the programme/project sponsors, of any of the views expressed. 


\section{Introduction}

It is a truism that economic development in the late twentieth and twenty-first century has followed paths which are profoundly different from those of the 'First World'. However, most discussions focus on the economic and technological environments which developing countries face. This paper looks instead at a curiously neglected phenomenon: the radically different opportunities for women in today's developing countries, and, specifically, the different role of women among the elites of early, and later, developers.

The broad outlines of development past and present are well rehearsed. First time around, a gradual growth in trade, and a comprehensive shift from subsistence to marketized agriculture preceded the industrial revolution and the enormous output growth and demographic transition that it engendered. When Britain became the first industrialized country, it did not have access to the huge global markets of today; and while the harnessing of carbon-based energy brought a rapid decline in the cost of transporting goods, these costs remained enormously high in purchasing power terms by the standards of 2010. Germany, France and the US industrialized a little later than the UK, but were not involved in anything like the sort of technology and productivity ‘catch-up' which characterize today's development successes.

Differences are very marked with respect to the flow of ideas and values. Intellectuals, and scientists of the mid nineteenth century were in contact with each other - as, indeed, Adam Smith was with his eighteenth century French and German contemporaries (Rothschild 2001) - but largely within a small group of Western countries. Economic and political ideas certainly spread, via these networks, and gave us a century of Communism. But there was nothing approaching a world language. Travel was expensive, even with the advent of the railways. Few books were translated. Members of future national elites attended universities in their home country. There was neither Hollywood nor Bollywood, and, obviously enough, no internet.

Today, we have something very close, in many ways, to a 'global village' (McLuhan 1962). Just 250 years ago, tiny numbers of the British rich - and only the rich - adopted the 'Grand Tour' as a way of educating their sons - and only their sons. Today, small farmers and labourers whose incomes are low, and whose countries are poor, and with large remaining sections of subsistence-agriculture, have access not only to TV and films but also to mobile telephony. Hundreds of millions of people, in countries with incomes per capita way below those of the US or Western Europe in 1910, have personal internet access. And the world's elites increasingly educate their children, male and female, for a global existence, in international schools, and 'top' universities, identified from high profile league tables (Wolf 2002).

This paper is about an important and surprisingly unnoticed aspect of economic development in this different twenty-first century world. The first time round, in nineteenth century Europe and America, women played very little direct role in the upper ranks of politics and business. If they were visible at all it was as appendages of a powerful man or through hereditary positions. In that sense, as much as any other, modern development is utterly different. 
Today, women in developing countries enter and occupy elite positions directly and independently, in large numbers. This is a profound difference; and it is one which, I will suggest, can only be explained by the international spread of ideas, and values through modern telecommunications and entertainment, by modern education and aid patterns, and, above all, by the increasingly international experiences of almost every country's elites, and of their children.

\section{Invisible women?}

One reason this dramatic difference has been so little remarked upon is the way in which women's affairs are reported. In developed countries, this is overwhelmingly in terms of cups-half-full, glass ceilings and the like (see, for example, Hewlett 2007). These make for good headlines. Grant Thornton International, for example, publishes an annual International Business Report which includes one of the few annual, international surveys of 'top' women in business - albeit in a particular section of it (namely, top privately owned companies). In 2009, they reported that between 2004 and 2008 there was 'only a marginal improvement' in the percentage of senior level management positions held by women in these businesses worldwide. 1 This 'marginal improvement' was from 19 per cent to 24 per cent - which one can also describe as an increase of over 25 per cent in the space of four years. So it does depend on your perspective!

The literature on developing countries, meanwhile, focuses largely on the experiences of the female poor. It is concerned with the extent to which schooling is equally accessible to boys and girls, and with addressing gender differences in literacy. 'Educate the women' is regarded as one of the best strategies - almost a cast-iron guarantee - for growth, and championed by aid agencies and campaigners (see, for example, Kristof and WuDunn 2009). Educated women, it is assumed, will take control of their fertility, educate their own children better, and adopt better health practices.

The sub-text here is that opportunities remain deeply unequal, and women a generally subjugated group. Kristof and WuDunn (2009), for example, focus on extraordinary and inspirational stories, such as the 'brothel slave' who becomes a businesswoman. And, indeed, for the population as a whole, opportunities are indeed highly unequal in many parts of the world. At the extreme, there remain countries and regions (such as those dominated by fundamentalist Islamic groups, including the Taliban) which deny the legitimacy of any formal education or formal labour market role for women.

However, this approach also tends to leave the impression that only small numbers of women are being educated in developing countries, and that all their women are oppressed, which is far from the truth. In reality, outside a very limited number of countries, the world has come to accept the idea that men and women should have equal opportunities in education and the workplace. This is itself a function of the rapid spread of ideas, values and assumptions across the contemporary globe. Of course not all countries are the same, but most of them sign up to a large number of common values. Even if the commitment to female equality is to a degree lip-service, this does not stop it having a concrete, substantive impact on legal codes, access to education, and social and economic behaviour. There are many millions of highly successful

1 www.internationalbusinessreport.com 
professional and business women in today's developing countries, and the gender composition of their elites has been transformed. Yet these highly successful women are invisible, ignored by women's studies and development literature alike.

This paper describes key aspects of this phenomenon, in order to demonstrate how different 'early' and 'late' development have been in terms of female elite participation. It highlights business, education and politics; and offers some tentative explanations. These striking differences will undoubtedly have implications for how development proceeds. I do not know of anyone who has teased this out systematically, but do speculate a little on what the implications might be for continuing differences between 'old' developed and 'new' developing nations and more specifically for their future elites.

\section{The first developed countries}

Two hundred years ago, in 1810, mainland Britain was on the verge of the industrial revolution: the first country to be so. It had banished famine long before: the last was in the 1620s, although other European countries experienced them for far longer. ${ }^{2}$ It had left subsistence agriculture behind: from the mid-seventeenth century onwards, the whole country was fully integrated into a market-based economy (Floud and Johnson 2004). The ideas of Adam Smith, for all that he was seen by many as a dangerous radical, were increasingly influential: free trade, competition, an extended franchise were the fundamental tenets of early nineteenth century liberalism (Rothschild 2001).

Yet although the economy was being transformed by entrepreneurs, business-owners, investors and inventors, hardly a single one of them was female. Victoria would be the 'defining' monarch of the coming century, but her position was entirely hereditary. The Duchess of Devonshire might have hit headlines and dominated gossip columns for trading kisses for votes in support of her favoured candidate, but British women were less empowered politically than they had been in many previous centuries, barred from voting by their gender even if they were property-owners and rate-payers. The dominant concerns of all women, across all social classes, were far more similar than they are today, and entirely domestic. Smith himself took this for granted. He hardly mentions women in 'The Wealth of Nations', and when he does it is to remark, admiringly, that women's education, determined entirely by their parent or guardian, all 'tends evidently to some useful purpose; either to improve the natural attractions of their person, or to form their mind to reserve, to modesty, to chastity, and to economy; to render them both likely to become the mistresses of a family and to behave properly when they have become such’ (Smith 1776: Book 5, chapter 1, Part 3).

Smith was being entirely realistic. This was all that educated, and, indeed all educated elite women's lives, did offer. This did not mean that such women - meaning the daughters, wives and mothers of elite men - were idle. In The Gentleman's Daughter, her wonderful study of eighteenth century women's lives, Amanda Vickery quotes one of her feminine subjects, writing that 'my time is always imployed and if I do take a pen I always meet with some interruption'. This would have been literal truth, certainly once child-bearing began. These women were responsible for running quite substantial

2 Including, notoriously, Ireland, ruled by Britain and still characterized, in the nineteenth century, by subsistence farming on a large scale. 
households, had demanding and recurring nursing duties; and also bore the main responsibility for bringing up, and for much of the education of their children, including teaching them to read and write (Vickery 1998).

Women have always worked and not just in caring for household and family. Elite women were unable to work for money: non-elite women could and did. For nonmarried women outside the affluent middle classes, full time work until marriage was, of necessity, quite as much a norm as it was for men.

From the mid-nineteenth century on, we know what women in industrializing countries did. The 1851 UK Census, for example, numbered thousands of female bookbinders, silk cloth manufacturers, artificial flower makers, and earthenware manufacturers, 50,000 female cooks and 675,000 general females domestics. But on the eve of the Great Exhibition, demonstrating Britain's industrial might to the world, and in a society which was highly urbanized, a world Empire, and the richest per capita in Europe, the only salaried middle-class females, were the 42,000 teachers it enumerated. Forty years on, in the 1891 census, there were still just 101 female physicians, though almost 2 million female industrial workers and 1.7 million female domestics.

By the early twentieth century a large proportion of wealth was held by women, but this was by inheritance, as there were a large number of wealthy widows. The first female MP to take her seat in the British Parliament did so only in 1919; she was Nancy Astor, a society hostess and an agitator for social reform. She was elected to Parliament just three years after the first woman was elected to the US House of Representatives. Barbara Wootton, one of the most eminent British women of her generation - and widowed, like so many, as a young World War I bride - became a magistrate in 1925, at the age of 28, two years before she would be allowed to vote! (Women had to be 30 to vote in Britain until 1929.)

\section{TABLES 1 AND 2}

What was true for politics was equally true for the professions, and business was even harder to penetrate. Table 1 (for the UK) and Table 2 (for the US) summarize the very slow rate at which women penetrated the professional and business elites in the sense of taking paid positions or heading their own firms and practices, as opposed to marrying elite men. Figure 1 uses the (typical) case of the UK to illustrate women's penetration of the universities; faster than for economic life, but still lagging behind men well into periods of very high income per capita, and advanced industrialization.

\section{FIGURE 1}

The critical point for my argument here is not that women were not equal; clearly they were not, as we all well know. What is remarkable is the degree of inequality, given the level of economic development. The charts cover years when income per capita in these countries was already significantly higher than for the big developing countries of today such as China, India, Indonesia. For many decades, when the 'First World' was enjoying income levels which have not yet been attained in the bulk of Asia and Africa, women played very little independent role in the labour market other than as servants, factory workers, cooks, and shop assistants. The only major exceptions to this pattern were teachers and nurses - jobs which led on directly from the traditional female roles of child care and sickroom attendant. They received the vote far later than men; they 
were barely represented in political life. As the rest of this paper shows, the situation in today's developing countries is manifestly different.

\section{$4 \quad$ Female elites in the developing world}

From the point of view of this paper, the key differences between 'first phase' development and current development can be demonstrated under three headings education, business and politics.

\subsection{Education}

The early stages of industrialization were also, in Europe and North America, periods when the state became directly involved in providing and paying for schooling. This happened with varying speed - sooner in Germany, later in England - and some historians have queried whether it was in any sense 'necessary'. (In England, for example, there was very high participation in elementary education well before the 1870 Education Act which nationalized most elementary schools and made attendance compulsory (West 1994). However, the general trend was uniform: a gradual move first to compulsory elementary and then to compulsory secondary schooling. Higher education has also expanded as developed countries have grown richer - again at varying speeds with the US having the fastest and earliest expansion (both in absolute terms and in relation to GDP per capita) and Switzerland the smallest. At every point women entered a given phase of education more slowly than men. 3

There are two striking difference between the pattern just described for 'first phase' developers, and what is happening in today's developing countries. The first is the overall level of formal education attained for a given level of GDP per capita. The second is the speed with which women are attaining equal (or higher) participation levels.

University education is of particular interest because of its role as a route into the elite. Figure 2 illustrates how university participation patterns developed among the early industrializers and some successful Asian countries. As it shows, participation has tended to remain quite low for many years, and then increase dramatically, in a 'reverse L' pattern that is common to every rich country (see Wolf 2002 for a discussion of this pattern). The US expansion came first; but European countries followed, generally at levels of per capita wealth which were slightly but not enormously higher than for the US case.

\section{FIGURE 2}

By contrast, the Asian countries shown had much higher participation levels for a given level of per capita income than any of the 'old' rich. The same is true for today's developing countries. For a given level of wealth, their university participation rates are far higher than was the case for the first industrializing countries.

3 With a single exception: teacher training colleges for elementary school teachers, which in some countries were separately organized. 
Second, and even more marked, are the relatively high levels of female participation which occurs in developing countries compared to the levels which characterized most developed countries as recently as the 1950s and 1960s. Table 3 illustrates this, showing the most recent available figures on the gender breakdown of the higher education student body for a range of 'old' developed countries and new developing ones. They are barely higher for the former than for the latter. In 'Type A' courses (what we think of traditional university study) all the developed countries now have a female majority: so do half the developing ones. In the more applied and vocational Type 4, major differences in countries' economies and their organization of higher vocational study make for major differences within the two groups (32 per cent female in Finland, 62 per cent in Belgium): but here too, what is striking is how close the distributions are for the developed and developing country groups.

\section{TABLE 3}

\section{What accounts for this change?}

These educational developments are a necessary condition - though by no means a sufficient one - for the female elite penetration of business and politics which I turn to below. So it is worth asking why they have occurred? Are they essentially economic, a response to delayed development which can be explained in terms of demand for skills?

Certainly today's developing countries need a very different skill mix than did Britain in 1810 or 1840, if they are to participate in the global economy. This is a world of trade laws, and record keeping; and one in which even a small agricultural exporter, deep in a rural area, must interact with suppliers and purchasers constantly, using both written (typed) messages and statistical packages. More generally, since they are playing 'catch-up', developing countries are orienting themselves to the technologies of today's developed world, not of the much less educated and technically advanced one of 1900 .

However, it is hard to see this as explaining such high levels of female participation in and of itself. Developing countries almost all have an over-supply of skills, especially those which are learned in classrooms - as, indeed, does the developed world (Wolf 2004). Just as European countries were all able to grow adequately with very little female participation in middle-class and professional jobs, right up until World War II, so, in principle, could today's developing countries. There are plenty of under-used male skills and abilities out there.

One has, instead, to look to ideas and values for a good part of the explanation. High levels of educational participation generally reflect deliberate government policies, based on beliefs that expanding education can and generate growth in and of itself, as much as they do labour market demand (see Wolf 2002 for a critique of this position). But equal, or near-equal, female participation, especially in the higher reaches of education, reflect the demands of a democratic electorate demanding opportunities for their children, and the preferences of the politically important middle classes.

In both government policy and citizen pressure and demands, the impact of modern values and ideas is clear. Governments not only pay lip-service to gender equality, but in many cases genuinely offer equal educational access to both girls and boys. (Aid agencies encourage this, but certainly cannot ensure it if a host society is opposed: and in any case, provide only a portion of the relevant funding in a portion of the developing 
world.) Critically, middle-class and wealthy families, in developing countries, ensure that their daughters are highly educated, and prepared for careers, in a way that neither their recent ancestors, nor those of today's Westerners, would have contemplated.

In this context, Figure 3 is highly illuminating. One feature of today's globe is the rise of international schooling, both secondary and tertiary. There is a global elite which increasingly attends the same undergraduate and graduate schools; and we can also chart the rise of English-language international schools for secondary education, used particularly by developing country elites. Their preferred graduating qualification is the International Baccalaureate: and Figure 3 shows the gender breakdown for recent candidate groups. Once again, what is striking, given the stage of development of many of these students' home countries, is the level of female participation. These students are financed by their parents, who are paying very high fees for their children's education: and they are paying for more daughters than sons.

\section{FIGURE 3}

\subsection{Business}

Most of the world's 'businessmen' are, indeed, men. But nothing like all. And again, this is an area where women's trajectory is quite different in the developing world from the one which characterized the first, or indeed second, wave of developed countries.

In the West, women's entry into business and commerce is very recent indeed - far more so than for the professions. To see how recent, it is worth looking - as I recently did - at the alumnae records of Somerville College Oxford. Somerville, one of Oxford University's first and most academic women's colleges, provides a good microcosm of female elite careers in the developed world over the last century and a bit. In 1888, for example, 10 years after the College was founded, only three ex-students are reported to be working other than as active teachers: one as a missionary, one a school manager and one a college principal. In 1938, the College Register summarized careers to date. Twenty-five of the 34 members of the class of 1896 are there. Just over a third had married, generally combining this with some form of volunteer and service work: the other two-thirds had not, and of this latter group all but four had made their careers in education - the exceptions being a nun, a hospital matron, a librarian and a health visitor.

As late as 1920, we find a (much larger) class matriculating of whom just two, an art dealer and a director of an iron-founders, made 'non-caring' careers. Teaching, at school or university level, remained the majority occupation by far for this generation, accounting for 80 per cent of those who reported recent or current paid employment.

Only when we get to the class of 1980 do things change. Here, only 10 per cent report a school-teaching career. They are outnumbered by accountants, and part of a group where bankers, management consultants and marketing managers are all more numerous than librarians or even university lecturers.

As a highly academic institution, this was unlikely to produce many entrepreneurs although it is, now, starting to produce top managers in FTSE 100 companies. But we can also see from national Censuses how slowly women were able to enter management in large firms or head their own small companies. It is not just the returns for 1910 (see 
Tables 1 and 2) that reveal tiny numbers of female business managers and owners. The same holds - for the US, UK, and other European countries - right through into the 1950s.

Contrast this with China, where income per capita is still, in 2010, below America's a century earlier. This is a country where girls were once valued so little that daughters were sometimes just numbered, without a proper name of their own, and where a market economy was embraced only in 1992.

But China is now home to Zhang Yin, with a personal fortune of US\$3.4 billion, from a scrap-paper and recycling business that she launched from scratch in the late 1980s. She is far from singular. Zhang Xin is the strategic head of the vast SOHO China development company she runs with her husband. Chen Ningning and Lu Hui created and chair Pioneer Metal Holdings; Yang Huiyan is another huge property developer. Meanwhile PepsiCo, for example, has a global CEO, Indra Nooyi, who is female and was both born and educated in India. America in 1910 had no such women.

Early feminists often argued that it is ridiculous for an economy to deny itself the output of half its educated brains. The fact that so many occupations were effectively closed to women, even in the post-war period, when households were increasingly easy to run, is a sign that values and attitudes can and do rule out what seems like obvious profitincreasing strategies. Today, while all major developing countries offer women more chances in business and commerce than Western countries did, differences between them again underline the importance of culture.

China is a front-runner in this respect, and, as so often, a comparison between it and India indicates how differently development can play out. The Grant Thornton International business reports estimate that, among large privately held businesses in China, women occupy about 31 per cent of senior management positions, one of the highest in the world; and that more than 80 per cent of such businesses have senior female managers. Chinese government statistics indicate that 41 per cent of private sector enterprise owners are women. While many of these will be tiny retail outlets, the figure is nonetheless much higher than for India. Indeed, as Table 4 shows, in terms of female representation within large businesses, China is very similar to the developed countries of the region.

\section{TABLE 4}

This is not to imply that there is gender equality - Figure 5, drawing on the full Census, makes this clear. But this is a country where, to repeat a previous point, GDP per capita is still below that of America in 1910 - a time when the US had no 'Forbes List' women entrepreneurs, no female senior managers in its big corporations, and not a single national-level female legislator.

It is, to belabour the point, at elite level that the contrasts are most striking. Thailand offers another example of this point. Across the economy as a whole, women remain under-represented in professional and managerial levels; international agencies do not rank the country very high on gender equality, and note the continuation of cultural norms and attitudes which militate against female advancement (Yukongdi 2009). Yet in family-owned and private companies - which are extremely important in the Thai economy - women have been doing very well indeed. The Grant Thornton International 
Business Report, referred to earlier, found that Thailand was one of the world's leaders in terms of female representation at senior level in large, privately held businesses, with 38 per cent of such positions held by women in 2009.

India offers an interesting comparison, for its differences and its similarities. Overall, in business, women have made far fewer inroads than in its fellow-giant, China, even though they have had some remarkable and high-profile successes - including in large, multinational, publicly quoted companies. Figures 4 and 5 show that Indian women remain a small proportion of managers and proprietors in the economy as a whole. The difference between India and China (like that between Japan and Singapore - see Table 4) reflects the importance of values and culture, interacting with economic development and business structure. That said, India also demonstrates the basic point that developing countries today offer women serious business opportunities that were never available to Western women in the first century and a half of industrialization. India is, after all, is a country with a vast, rural hinterland, less 'advanced' in terms of engagement with the market than anywhere and everywhere on the British mainland in 1900, 1800 or indeed 1700 .

\section{FIGURES 4 AND 5}

\subsection{Politics}

Until very recently, all women in politics owed their position to family connections. But increasingly, independent women politicians are appearing - and again, not only in the West (Margaret Thatcher, Angela Merkel) but in the developing world. And while family remains important, especially in the developing world (as, indeed, it does in business), it is no longer a prerequisite for success. India, for example, has seen the rise of very powerful female politicians with no family base - Kumari Mayawati, Jayalalitha Jayaram and Mamata Banerjee among them. They had no equivalents in nineteenth or indeed most of twentieth century Europe or North America.

As with education, the economy is not an adequate explanation. But it is surely critical that most of the world's developing countries today have universal suffrage: most of the developed world, when they were at this level of income did not. This does not mean that women vote for female candidates: There is nothing to suggest, anywhere in today's developed or developing world, that a candidate's gender is critically important in how women vote. But it does indicate that it is now completely unacceptable and illegitimate, outside a very few countries, to discriminate explicitly by gender with respect to suffrage and access to legislative office.

Women remain the minority - often a small minority - of politicians in most countries of the globe. But once again, what is striking is the difference between developing and developed world in terms of female representation at a given stage of wealth acquisition. Indeed, on this indicator - see Table 5 - the countries which are world 'leaders' in terms of female representation in politics are as likely to be developing (and often African) as Western. The Scandinavians are predictably high in the 'female legislators' rankings: but it is Rwanda which is top, and more than half the top twentyfive are developing nations. 


\section{ELITE WOMEN: THE ADVANTAGES OF LIFE IN A DEVELOPING COUNTRY}

In the discussion so far, I have emphasized how ideas and values, dominant in today's developed world, have also been adopted by today's developing countries and led to opportunities for women which never existed in the early periods of industrialization. Elite women in developing countries are the greatest beneficiaries of this, and of the way in which values and perceptions have moved across the globe far faster than wealth has equalized. They benefit at home and are also, again unlike their predecessors, able to lead very international lives themselves.

Developing country elites, especially the female members, in key respects, have an easier time of it than the elites of the developed world. They have domestic help and not only is it cheap, but it is legitimate and 'normal'. An elite female in the contemporary US or UK, working in a job which put her in the top 10 per cent of earnings, can easily find that her whole post-tax salary just covers the cost of domestic help in the form of one nanny and a part-time cleaner. This would not be true for her Indian equivalent today. And at a time when domestic labour was cheap in the now-developed world, most of the professional job market was closed to women.

Understanding the domestic context of elite women's lives is also important because of the general importance of family. Family connections matter in all societies, but they are critical in understanding how and why female elites have become so much more prominent in today's developing countries than they were a century ago in the West. The pattern of female political leaders, inheriting fathers' or husbands' mantles, has been much emphasized and is indeed still important - Indira Gandhi and Sonia in India, Benazir Bhutto in Pakistan, Cory Aquino in the Philippines. But as we saw earlier, there are also increasing numbers of female politicians who are not daughters, sisters, widows. What is happening, though is a more general 'family inheritance' pattern, which encompasses the whole business sector, as well as spilling into politics.

The key point is that families - fathers, parents - do not, today, particularly favour sons over daughters. They educate them alike (in the context of smaller families); involve them both in the business; and while a son-in-law may be actively engaged in the business into which he married, so, today, is the boss's daughter who brought him there. This, I would argue, illustrates once again the importance of changing, international values and attitudes in helping to explain behaviour, and, specifically, female elite formation.

Because government and business opportunities are, in many developing countries, intertwined in a very open and personal way, this can generate 'power couples' and 'power families' with very far-reaching interests and power. (Russia and South Africa both afford striking examples; while in China, many of the privileged children of the Politburo have accumulated business interests.) Particularly striking in this context are the 'family-states' of Central Asia: Kazakhstan, Kyrgyzstan, Uzbekistan, Turkmenistan and Tadjikistan (Kydyralieva 2009). All five were communist until recently, none has established a stable democracy; moreover, all are Islamic, and so might be expected, $a$ priori, to treat men and women very differently. ${ }^{4}$ But in fact, what is happening is that,

4 In fact, the central Asian republics have been rather more like Europe, and rather less like the Arab states, than one might expect from their religion (Weatherford 2010). 
in every case, ruling presidents have trusted, promoted, and ruled through their daughters as much as their sons. States where ruling families expropriate national wealth are nothing new. But 'family-states' practising gender equality in this way are new.

What of the future? With the rise of female education, married couples across the world are increasingly 'assortatively mated' in education and career terms, especially in the elites. And one clear result of the 'costs' of family life in the developed world is that elite women have very few children and the same is true of elite men. Of course, birthrates have dropped everywhere, while remaining highest in the poorest countries, and are higher, within countries, among the poor.

Nonetheless, here too, there are differences between the elites of the developed and developing worlds. In India, for example, graduate women are overwhelmingly likely to marry - over 95 per cent do - and also far more likely to bear children than their Western counterparts. Among Indian graduate women aged between 35 and 39 at the last Census, less than 10 per cent were childless. The comparable figures for the US and UK is over a third. Moreover, in India, a half of those female graduates who have been married had 2 children, and a fifth had 3 or more - a much higher fertility rate than is common among educated women in the west. And these are not a tiny minority on the contrary, they are part of a generation which experienced a doubling in female graduate numbers from 733,000 to 1,493,000 (with a further doubling, incidentally, for those ten years younger.)

In the West, there has been considerable and growing concern about social mobility and its perceived decline. But in fact, given the failure of either elite men or elite women to reproduce themselves as a group - the mean fertility rate for Harvard/Radcliffe women and Harvard/Radcliffe men is less than 1.5 - there is bound to be mobility into the top echelons of society even if all the children of elite, assortatively sorted couples do well themselves (Goldin and Katz 2008).

In developing countries, the rapid expansion of middle class jobs, under conditions of high economic growth, ensures that the absolute number of highly 'desirable' jobs grows fast without requiring downward mobility in order to open up vacancies. But at the very very top, current patterns - female education in elite schools, career success, plus higher birthrates - make it quite possible to imagine that very closed elites, made up of powerful political and business families, will be able to perpetuate themselves for a long time. New-style development is very good for equal opportunity in gender terms. It is not obvious that it will necessarily be more 'equal opportunity', this time round, in any other way. 


\section{References}

Floud, R., and P. Johnson (eds) (2004). The Cambridge Economic History of Modern Britain, Vol. I. Cambridge: Cambridge University Press.

Goldin, C., and L. F. Katz (2008). 'Transitions: Career and Family Life Cycles of the Educational Elite'. American Economic Review: Papers and Proceedings, 98 (2): 363-69.

Hewlett, S. A. (2007). Off-ramps and On-ramps: Keeping Talented Women on the Road to Success. Boston, MA: Harvard Business School Press.

Kristof, N., and S. WuDunn (2009). Half the Sky: Turning Oppression into Opportunity for Women Worldwide. New York: Random House.

Kydyralieva, S. (2009). Elites of Central Asia and Economic Development. Mimeo. Institute of Social Science: Istanbul University.

McLuhan, M. (1962). The Gutenberg Galaxy: The Making of Typographic Man. Toronto: University of Toronto Press.

Rothschild, E. (2001). Economic Sentiments: Adam Smith, Condorcet and the Enlightenment. Cambridge, MA: Harvard University Press.

Smith, A. (1776). The Wealth of Nations. Available at: www.gutenberg.org/files/3300/3300-h/3300-h.htm

Vickery, A. (1998). The Gentleman's Daughter. New Haven, CT: Yale University Press.

Weatherford, J. (2010). The Secret History of the Mongol Queens. New York, NY: Crown Publishers.

West, E. G. (1994). Education and the State: A Study in Political Economy. Indianapolis, IN: Liberty Fund.

Wolf, A. (2002). Does Education Matter? Myths about Education and Economic Growth. Harmondsworth, Middlesex: Penguin.

Wolf, A. (2004). 'Education and Economic Performance: Simplistic Theories and Their Policy Consequences’. Oxford Review of Economic Policy, 20 (2): 315-33.

Yukongdi, V. (2009). 'The Changing Face of Women Managers in Thailand'. In C. Rowkey, and V. Yukongdi (eds), The Changing Face of Women Managers in Asia. Abingdon: Taylor \& Francis. 
Table 1: Female labour force participation, UK 1891

\begin{tabular}{llll}
\hline Percentage of all females: & & $\begin{array}{l}\text { Percentage of total } \\
\text { number employed who } \\
\text { were female: }\end{array}$ & \\
\hline In labour force5 & 35 & $\begin{array}{l}\text { All occupations classified } \\
\text { as 'professional' }\end{array}$ & 49 \\
$\begin{array}{l}\text { In occupations classified as } \\
\text { 'professional' }\end{array}$ & 3 & $\begin{array}{l}\text { 'Professional' occupations } \\
\text { excluding nursing }\end{array}$ & 43 \\
$\begin{array}{l}\text { Percentage of employed } \\
\text { females }\end{array}$ & & $\begin{array}{l}\text { 'Professional' occupations } \\
\text { excluding nursing and } \\
\text { teaching }\end{array}$ & 17 \\
$\begin{array}{l}\text { In 'professional' occupations } \\
\begin{array}{l}\text { In 'professional' occupations, } \\
\text { excluding teaching and } \\
\text { nursing }\end{array}\end{array} \quad 1 \quad \begin{array}{l}\text { Engineers } \\
\text { Lawyers }\end{array}$ & 0 \\
\hline
\end{tabular}

Source: UK Census, 1891.

Note: In the 2001 UK Census men accounted for 66 per cent of managers and senior officials; and 59 per cent of professional occupations. Although women still heavily outnumbered men among 'teaching and research professionals', they also accounted for 14 per cent of science and technology professionals. There were 106,000 such female science professionals and 856,000 corporate managers: the latter accounted for 8 per cent of total female employment and 14 per cent of male.

5 This is higher than for the US where the per cent of females age 10+ who were gainfully employed was only 14.7 per cent in 1880 and 23.4 per cent in 1910. This almost certainly reflects the greater role of agriculture - and more specifically of family farms - in the US economy: as late as 1910. Thirty-six per cent of employed males and 22 per cent of females worked in agriculture. 
Table 2: Professionals and managers: gender break-down, US 1910

\begin{tabular}{|c|c|c|c|c|}
\hline & Total & Male & Female & \\
\hline Population 10 years of age and over & $71,580,270$ & $37,027,558$ & $34,552,712$ & \\
\hline Industry and occupation & Total & Male & Female & $\begin{array}{r}\text { Female workers } \\
\text { in this category } \\
\text { as } \% \text { of female } \\
\text { population }\end{array}$ \\
\hline Bankers, brokers and money lenders & 105,804 & 103,170 & 2,634 & 0.000076 \\
\hline Bankers and bank officials & 56,059 & 54,387 & 1,672 & 0.000048 \\
\hline Commercial brokers and commission men & 24,009 & 23,690 & 319 & 0.0000092 \\
\hline Loan brokers and loan company officials & 2,111 & 1,989 & 122 & 0.0000035 \\
\hline Stockbrokers & 13,729 & 13,522 & 207 & 0.0000059 \\
\hline Pawnbrokers & 1,232 & 1,191 & 41 & 0.0000012 \\
\hline Brokers not specified and promoters & 8,664 & 8,391 & 273 & 0.0000079 \\
\hline Insurance agents and officials & 97,964 & 95,302 & 2,652 & 0.000077 \\
\hline Insurance agents & 88,463 & 85,926 & 2,537 & 0.000073 \\
\hline Officials of insurance companies & 9,501 & 9,376 & 125 & 0.0000036 \\
\hline Proprietors, officials, and managers & 22,862 & 21,352 & 1,010 & 0.000029 \\
\hline Employment office keepers & 2,260 & 1,540 & 720 & 0.000021 \\
\hline Proprietors, etc., warehouses & 4,393 & 4,868 & 25 & 0.00000072 \\
\hline Other proprietors, officials and managers & 10,591 & 10,339 & 252 & 0.0000073 \\
\hline Real estate (agents and officials) & 125,862 & 122,935 & 2,927 & 0.000084 \\
\hline $\begin{array}{l}\text { Manufacturing managers \& supt.s } \\
\text { Wholesale merchants and dealers (importers and }\end{array}$ & 104,201 & 102,748 & 1,462 & 0.000042 \\
\hline exporters) & 4,905 & 4,722 & 183 & 0.0000053 \\
\hline Judges, justices and magistrates & 6,816 & 6,816 & 0 & 0 \\
\hline Lawyers & 107,888 & 107,330 & 558 & 0.000016 \\
\hline Abstractors, notaries, and justices of the peace & 7,445 & 6,660 & 785 & 0.000023 \\
\hline Professors in colleges and universities & 15,668 & 12,710 & 2,958 & 0.000086 \\
\hline Teachers (athletics, dancing etc.) & 3,931 & 2,768 & 1,163 & 0.000034 \\
\hline Teachers (school) & 595,306 & 118,442 & 470,804 & 1.36 \\
\hline Electricians, engineers \& surveyors & 204,875 & 204,778 & 97 & 0.00000028 \\
\hline
\end{tabular}

Source: US Census, 1910, Volume 4: Population: Occupation Statistics. 
Table 3: Female participation in higher education, for selected developed and developing countries' percentage female graduates, first degree

\begin{tabular}{lcc}
\hline $\begin{array}{l}\text { Country (most recent } \\
\text { available figures) }\end{array}$ & Tertiary (type B) & Tertiary (type A) \\
\hline Brazil 2004 & 39 & 64 \\
China 2005/6 & 47 & 44 \\
Indonesia 2004/5 & 46 & 48 \\
Jordan 2004/5 & 63 & 52 \\
Peru 2005 & 58 & $\mathrm{n} / \mathrm{a}$ \\
Thailand 2004/5 & 34 & 60 \\
& & \\
Australia 2005 & 53 & 59 \\
Belgium 2004/5 & 62 & 54 \\
Finland 2003/4 & 32 & 63 \\
Germany 2004/5 & 61 & 51 \\
Spain 2004/5 & 53 & 60 \\
USA 2004/5 & 61 & 57 \\
\hline
\end{tabular}

Source: UNESCO World Education Indicators 2007.

Table 4: Average female representation in the workforce of the 10 largest multi-nationals operating in East Asia

\begin{tabular}{lccccc}
\hline Country & $\begin{array}{c}\text { \% in total } \\
\text { workforce of } \\
\text { companies }\end{array}$ & $\begin{array}{c}\text { \% in junior } \\
\text { level } \\
\text { positions }\end{array}$ & $\begin{array}{c}\text { \% in mid- } \\
\text { level } \\
\text { positions }\end{array}$ & $\begin{array}{c}\text { \% in senior } \\
\text { positions }\end{array}$ & $\begin{array}{c}\text { (\% of total } \\
\text { national } \\
\text { workforce } \\
\text { which is } \\
\text { female })\end{array}$ \\
\hline China & 44.3 & 53.5 & 28.7 & 13 & 45 \\
India & 28.1 & 34.1 & 16.2 & 8.2 & 18 \\
Japan & 41.2 & 50 & 20.7 & 8.9 & 41 \\
Singapore & 40.1 & 52 & 34.4 & 17.3 & 43 \\
\hline
\end{tabular}

Sources: Gender Diversity in Asia report by Community Business, Hong Kong (www.communitybusiness.org); ILO statistics. 
Table 5: Women's share as legislators in lower or single legislative House, May 2009

\begin{tabular}{|l|c|l|c|}
\hline 1. Rwanda & 56.3 & 13. Norway & 36.1 \\
\hline 2. Sweden & 47 & 14. Belgium & 35.3 \\
\hline 3. South Africa & 43.5 & 15 Mozambique & 34.8 \\
\hline 4. Cuba & 43.2 & 16. New Zealand & 33.6 \\
\hline 5. Iceland & 42.9 & 17. Nepal & 33.2 \\
\hline 6. Finland & 41.5 & 18. Germany & 32.2 \\
\hline 7. Netherlands & 41.3 & 20. Belarus & 31.8 \\
\hline 8. Argentina & 40 & 21. Uganda & 30.7 \\
\hline 9. Denmark & 38 & 22. Burundi & 30.5 \\
\hline 10. Angola & 37.3 & 23. Tanzania & 30.4 \\
\hline 11. Costa Rica & 36.8 & 24.Guyana & 30 \\
\hline 12. Spain & 36.3 & 25 Timor-Lests & 29.2 \\
\hline
\end{tabular}

Source: Inter-Parliamentary Union.

Note: No. 19 is Andorra. China is 53, UK is 60, France is 66, USA is 72, India is 99, Japan is 105.

Figure 1: University enrolment patterns in a developed country: male and female students in the UK, $1900-2000$

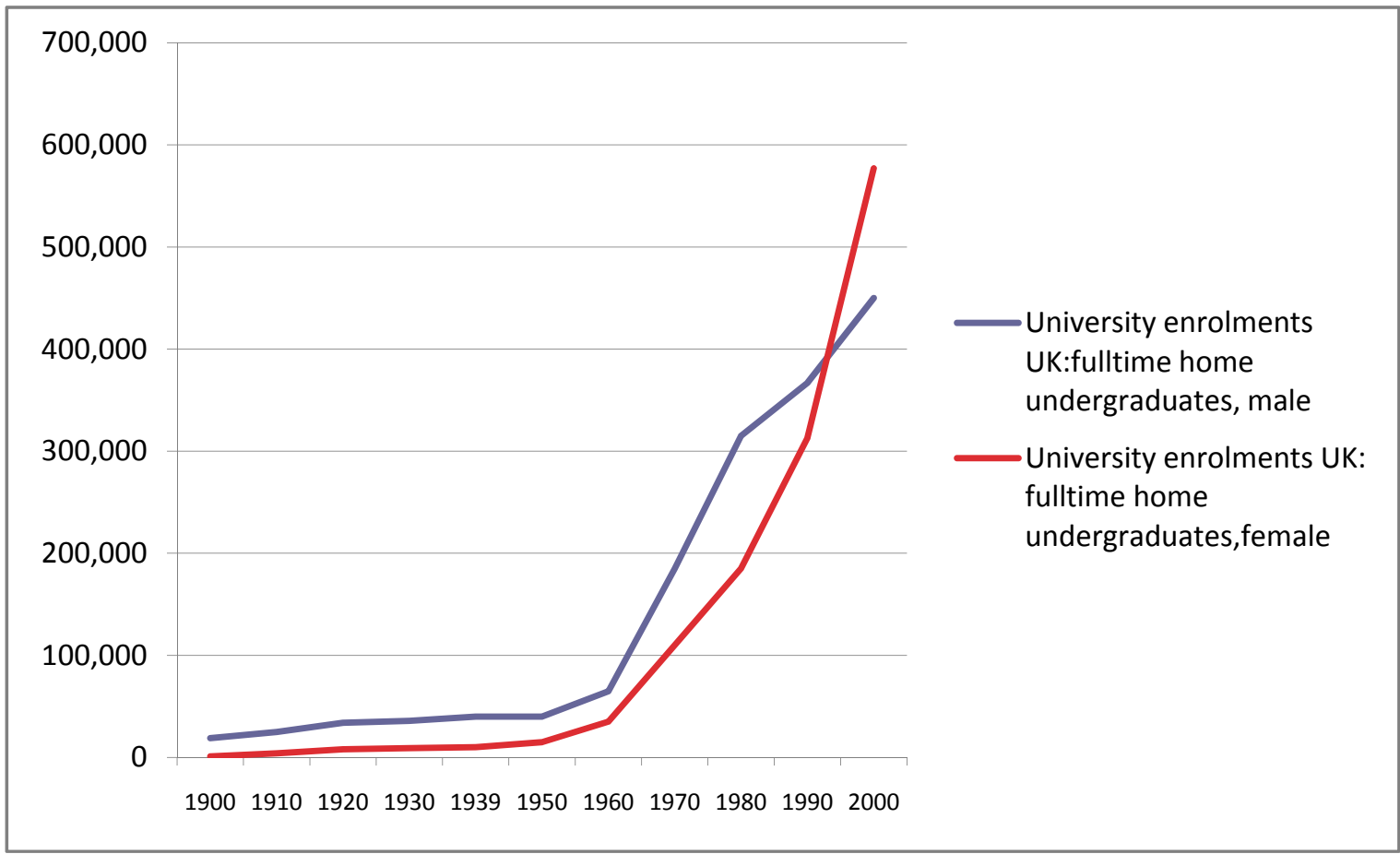

Note: Fulltime enrolment are overwhelmingly composed of young recent school-leavers. This is the dominant pattern for children from elite and middle-class families. 
Figure 2: The expansion of higher education in selected countries: proportion of school-leavers proceeding to higher education

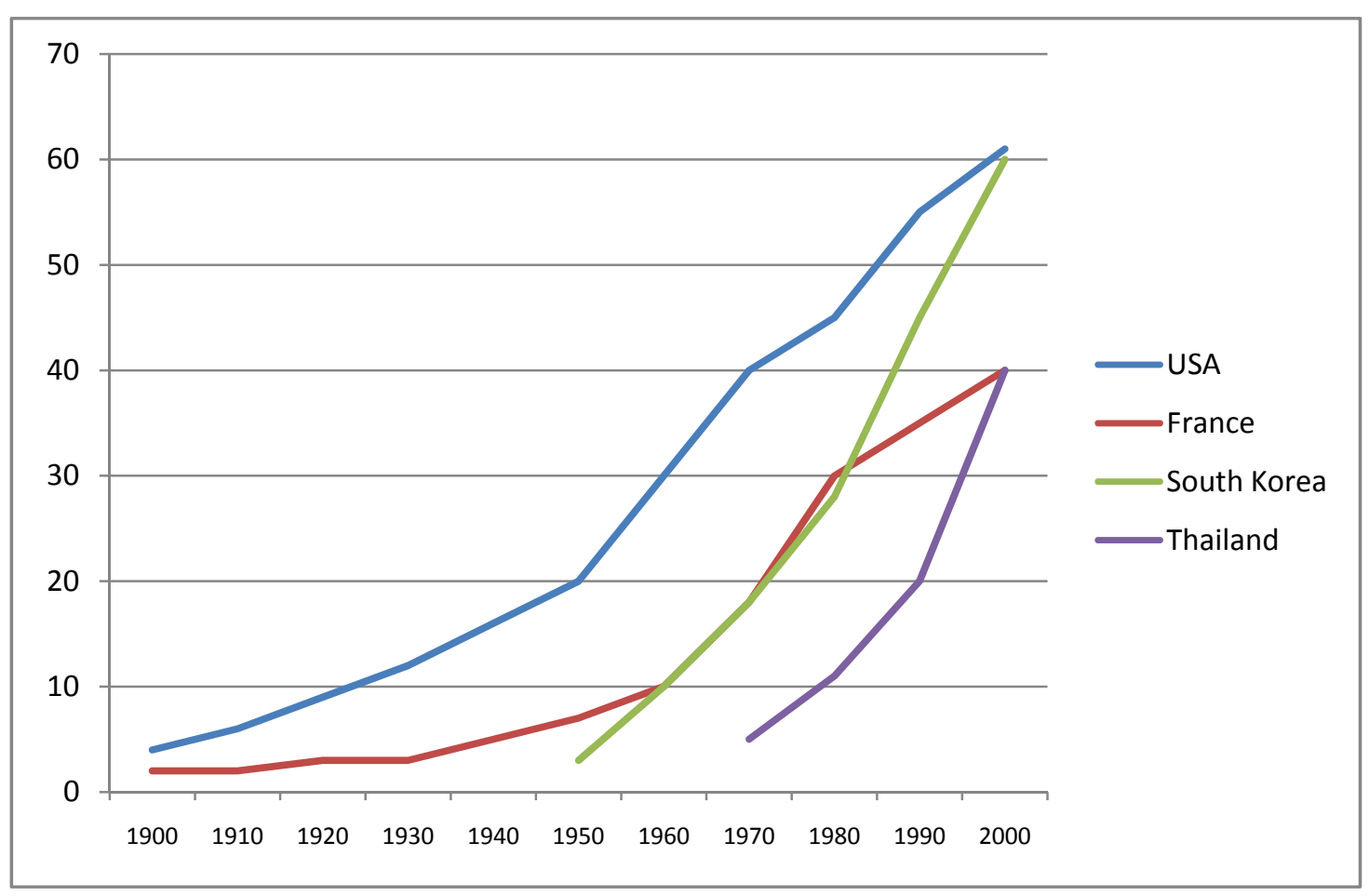

Source: OECD, UNESCO, French Ministry of Education statistics.

Figure 3: Male and female candidates for the International Baccalareate

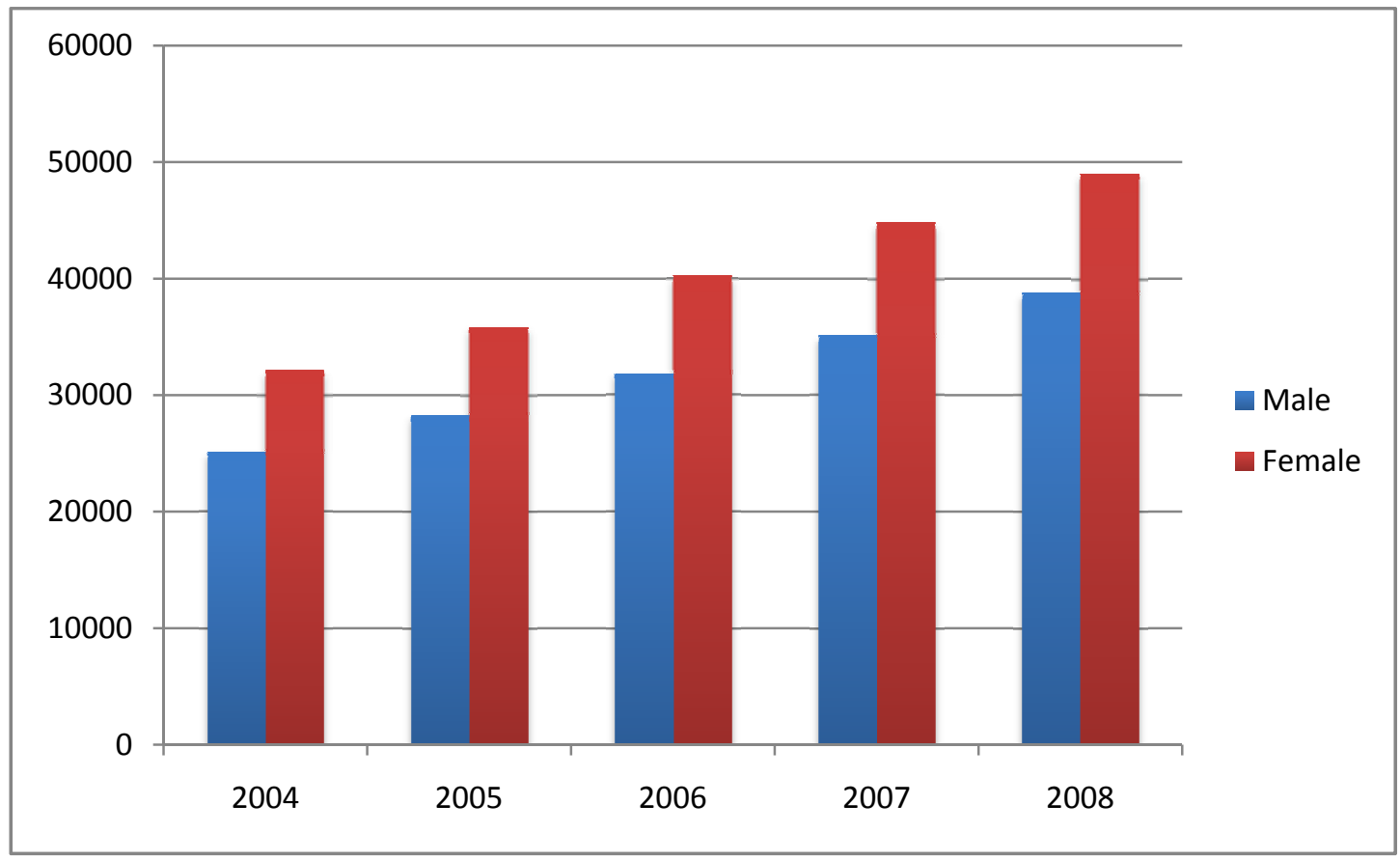

Source: International Baccalaureate: The IB Diploma Programme Statistical Bulletin May 2008 Examination Session. 
Figure 4: Gender breakdown for working proprietors and directors, India 2001, Urban areas only

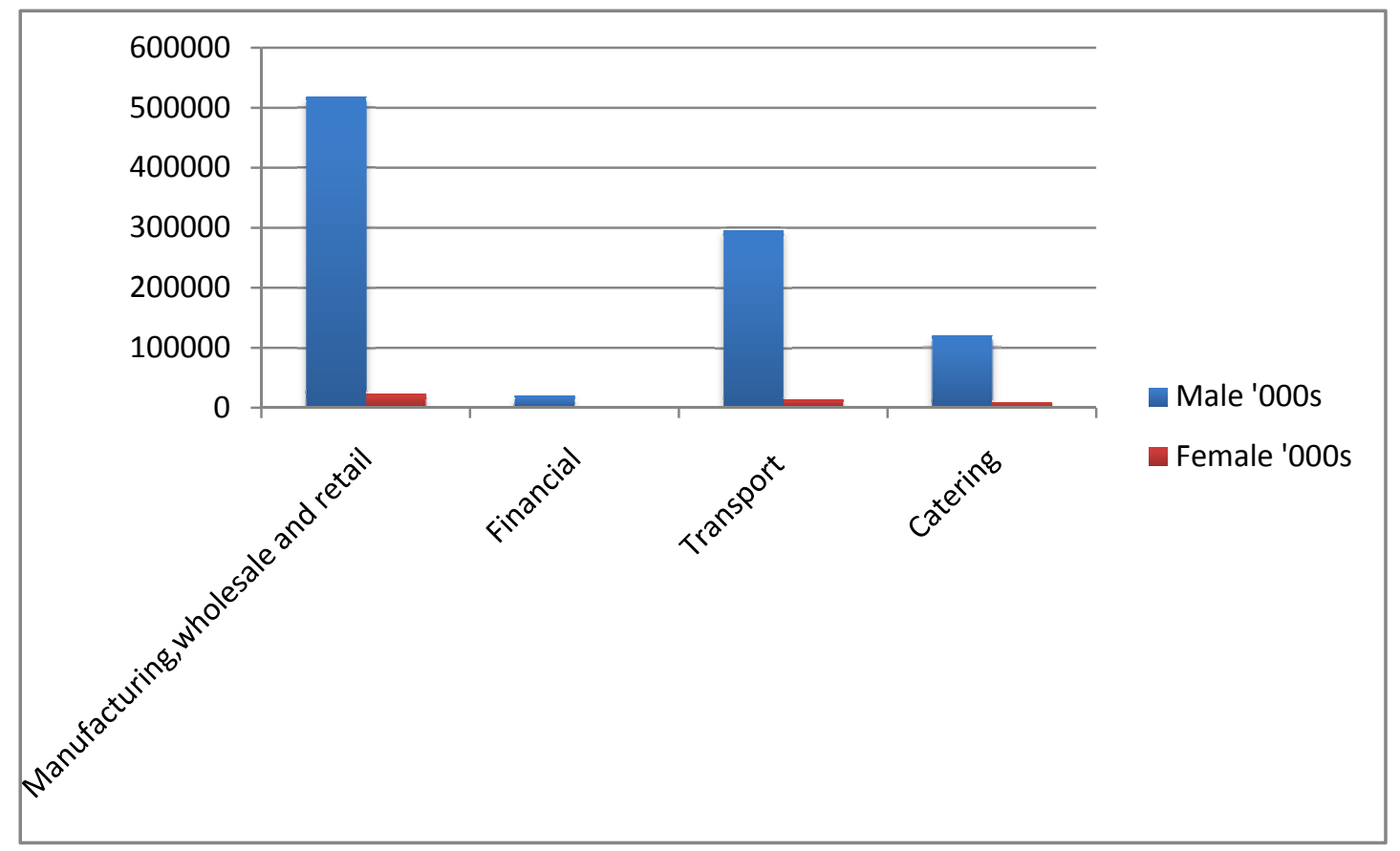

Source: Census of India 2001 Table B-25.

Figure 5: Gender breakdown for production and operations department managers, India 2001, Urban areas only

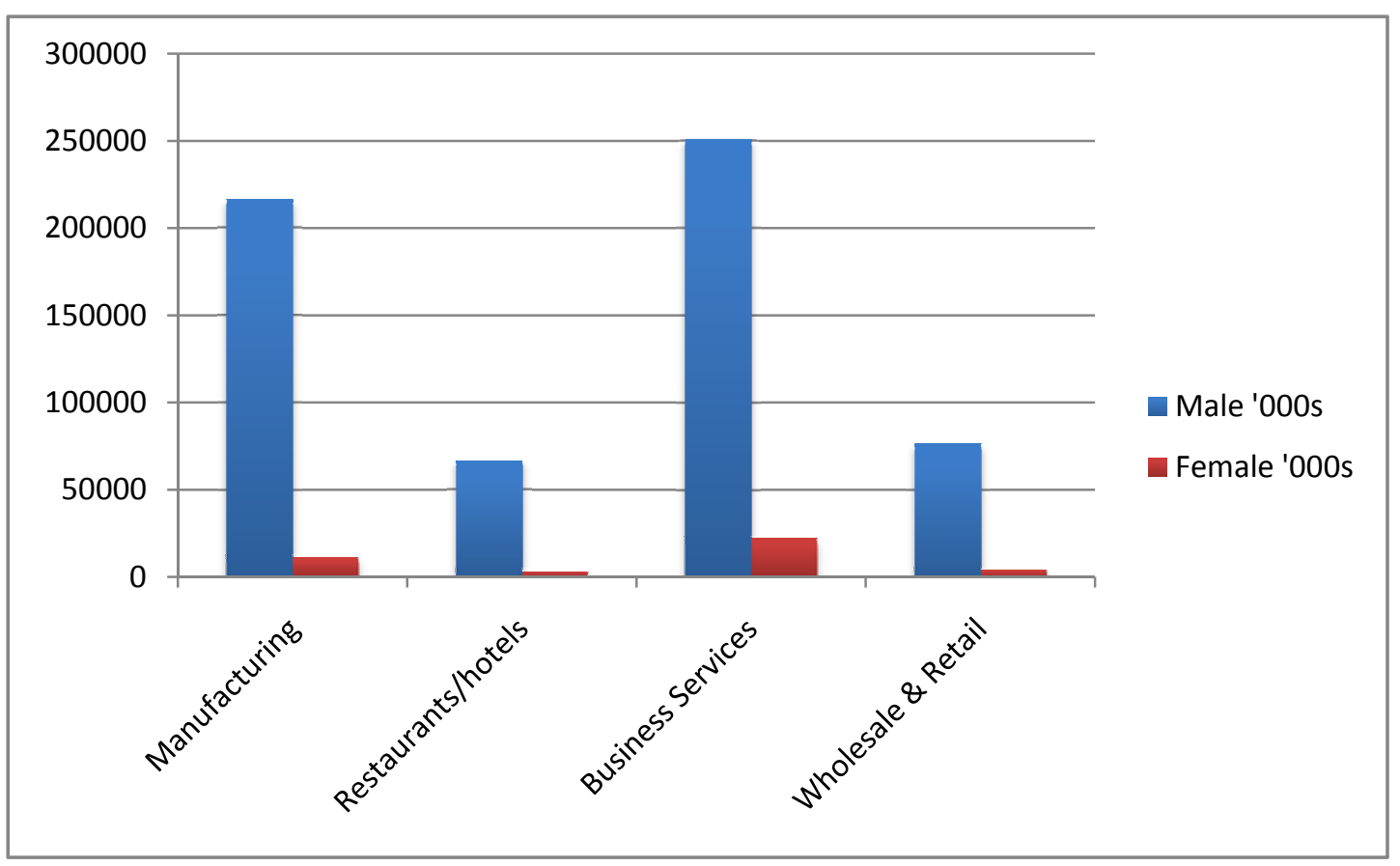

Source: Census of India 2001 Table B-25. 